\title{
Influences of bioactive substances on the physicochemical and functional stability of sunscreen emulsions
}

\author{
Influência de substâncias bioativas na estabilidade fisico-química e funcional de \\ emulsões fotoprotetoras
}

\author{
Maria Valéria Velasco, Fernanda Daud Sarruf, Camila Areias de Oliveira*, Ana Paula Miranda da Silva, \\ Vladi Olga Consiglieri, Telma Mary Kaneko \& André Rolim Baby \\ Laboratory of Cosmetology, Department of Pharmacy, School of Pharmaceutical Sciences of University of São \\ Paulo, 580 Prof. Lineu Prestes Av., Bl. 13/15, Conjunto das Químicas, Cidade Universitária, 05508-900 São \\ Paulo, SP, Brasil \\ *Email: milaareias@usp.br (C. A. Oliveira).
}

\begin{abstract}
The usage of isolated ultraviolet filters in photoprotective formulations produces products with limited protection against the solar radiations, which highlights the need for active compounds (filters and bioactive compounds) combinations. Previous studies have demonstrated that rutin, a bioactive compound, interacts with filters incorporated in sunscreens. Therefore, this work aimed at evaluating the influence of rutin on the physicochemical and functional stability of sunscreen emulsions. Sixteen formulations were developed, submitted to the Preliminary Stability Testing and characterized according to $\mathrm{pH}$ value, rheological profile and in vitro photoprotective efficacy. The formulation with the best performance and the correspondent formulation without rutin were submitted to the Normal Stability Testing. All formulations presented $\mathrm{pH}$ values compatible with the skin and similar rheological behavior. Formulation F16 and the same formulation without rutin were submitted to the Normal Stability Testing and presented similar $\mathrm{pH}$ values and rheological profiles that were maintained during the days of analysis. The antioxidant activity was stable only for formulations stored at $5.0 \pm 0.5^{\circ} \mathrm{C}$. The in vitro photoprotective efficacy demonstrated similar results among both formulations that were also observed on all days of analysis.
\end{abstract}

Keywords: Rutin; Ethylexyl methocycinnamate; Benzophenone-3; Titanium dioxide; Sunscreen.

\begin{abstract}
Resumo
A utilização de filtros ultravioletas isolados em formulações fotoprotetoras, origina produtos com proteção limitada contra as radiações solares, o que evidencia a necessidade de associar compostos bioativos. Estudos anteriores demonstraram que a rutina, um composto bioativo, interage sinergicamente com filtros solares incorporados em preparações fotoprotetoras. Portanto, este trabalho teve como objetivo avaliar a influência da rutina sobre a estabilidade físico-química e funcional de emulsões fotoprotetoras. 16 formulações foram desenvolvidas, submetidas ao teste de estabilidade preliminar e caracterizadas de acordo com o pH, perfil reológico e eficácia fotoprotetora in vitro . A formulação com o melhor desempenho e a formulação correspondente, sem rutina, foram submetidos ao teste de estabilidade normal. Todas as formulações apresentaram valores de $\mathrm{pH}$ compatível com a pele e comportamento reológico semelhante. A formulação F16 e a mesma formulação, sem rutina, foram submetidas ao teste de estabilidade normal e apresentaram valores de $\mathrm{pH}$ semelhantes e perfis reológicos que foram mantidos ao longo dos dias de análise. A atividade antirradicalar foi estável apenas para formulações armazenadas a $5,0 \pm 0,5^{\circ} \mathrm{C}$. A eficácia fotoprotetora demonstrou resultados semelhantes entre ambas as formulações, que também foi observado em todos os dias de análise. Em conclusão, rutina não influenciou a fotoestabilidade da formulação sob as condições adotadas.
\end{abstract}

Palavras-chave: Rutina; Etilhexil Metoxicinamato; Benzofenona-3; Dióxido de Titânio; Protetor Solar. 


\section{Introduction}

The human organism possesses endogenous mechanisms for the avoidance of damages caused by exposure to solar radiations, such as melanogenesis and stratum corneum thickening, amongst others. However, these mechanisms are insufficient thus making it necessary to resort to other strategies so as to minimize those damages ${ }^{[1 ; 2]}$

Therefore, the use of photoprotective formulations is of the utmost importance, as they consist of products employed to attenuate the deleterious effects of solar radiations ${ }^{[3 ; 4]}$. These products contain organic and inorganic filters as active compounds ${ }^{[3]}$. However, not only the filters but the whole formulation interferes with its photoprotective efficacy ${ }^{[5]}$. Inorganic filters act as a physical barrier against solar radiation, hence reflecting and dispersing it. They are safer and have a lower tendency to cause allergic reactions. Organic filters absorb ultraviolet radiations and convert them into less harmful ones. These types of filters, however, may cause allergic reactions ${ }^{[6]}$.

The use of isolated filters in photoprotective formulations produces products with limited protection and reduced efficacy. Therefore, the association of filters is recommended in order to obtain broad spectrum and more efficient formulations (higher Sun Protection Factor - SPF - values). This allows the use of a reduced concentration of each isolated filter because of the synergic effect, thus reducing the possibility of allergic reactions ${ }^{[7]}$.

Not only filters may be used for synergic effect, but also natural or bioactive compounds may be associated with filters to increase the formulation's efficacy. This is due to the chemical structure's similarities between these compounds and organic filters, which suggests that these compounds may exert photoprotective activity ${ }^{[8,9]}$. One possible bioactive compound is rutina flavonoid with antioxidant properties and topical action that possesses an absorption spectrum similar to organic filters due to the similarity between their chemical structure ${ }^{[9]}$.

Our research group has recently studied in vitro the interaction of bioactive compounds with organic and inorganic filters incorporated in photoprotective emulsions through diffuse reflectance spectroscopy. Previous studies have demonstrated that these compounds interacted positively and negatively with filters, depending on the bioactive compound and the UV filters' concentrations ${ }^{[8]}$.

To continue the investigation concerning the behavior of bioactive compounds on photoprotective formulations, the influence of rutin on the physicochemical and functional stability of a sunscreen emulsion was studied.

\section{Introdução}

O organismo humano possui mecanismos endógenos para a prevenção de danos causados pela exposição a radiações solares, como a melanogênese e espessamento do estrato córneo, entre outros. No entanto, estes mecanismos são insuficientes, tornando necessário recorrer a outras estratégias de modo a minimizar os danos ${ }^{[1,2] .}$

Portanto, a utilização de formulações fotoprotetoras é da maior importância, uma vez que consistem de produtos utilizados para atenuar os efeitos deletérios da radiação solar ${ }^{[3,4]}$. Esses produtos contêm filtros orgânicos e inorgânicos, como compostos ativos ${ }^{[3]}$. No entanto, não só os filtros, mas todos os componentes da formulação interferem na sua eficácia fotoprotetora ${ }^{[5]}$. Filtros inorgânicos atuam como uma barreira física contra a radiação solar, refletindo e dispersando-a. Eles são mais seguros e apresentam uma menor tendência para ocasionar reações alérgicas. Filtros orgânicos absorvem as radiações ultravioletas convertendo-as em radiações menos prejudiciais. Esses tipos de filtros, no entanto, podem causar reações alérgicas ${ }^{[6]}$.

$\mathrm{O}$ uso de filtros isolados em formulações fotoprotetoras origina produtos com uma proteção limitada e eficácia reduzida. Portanto, a associação de filtros é recomendada a fim de obter amplo espectro e formulações mais eficazes (Fator de Proteção Solar superior - FPS). Isto permite o uso de uma concentração reduzida de cada filtro isolado por causa do efeito sinérgico, reduzindo assim a possibilidade de reações alérgicas ${ }^{[7]}$.

Não apenas filtros podem ser utilizados para o efeito sinérgico, mas também compostos naturais ou bioativos podem ser associados com filtros, para o aumento da eficácia fotoprotetora da formulação. Isto ocorre devido às semelhanças na estrutura química entre estes compostos e os filtros orgânicos, o que sugere que estes compostos podem exercer atividade fotoprotetora ${ }^{[8,9]}$. Um composto bioativo possível é a rutina - um flavonoide com propriedades antioxidantes e ação tópica que possui um espectro de absorção semelhante aos filtros orgânicos devido à semelhança entre as suas estruturas químicas ${ }^{[9]}$.

Nosso grupo de pesquisa, recentemente, estudou a interação in vitro de compostos bioativos com filtros orgânicos e inorgânicos incorporados em emulsões fotoprotetoras através de espectrofotometria de refletância com esfera de integração. Os estudos anteriores demonstraram que estes compostos interagem com os filtros positiva e negativamente, dependendo do composto bioativo e das concentrações dos filtros $\mathrm{UV}^{[8]}$.

Para continuar a investigação sobre o comportamento de compostos bioativos sobre formulações fotoprotetoras, foi verificada a influência da rutina sobre a estabilidade físico-química e funcional de uma emulsão antissolar. 
Table 1 - Qualitative and quantitative ( $\% \mathrm{w} / \mathrm{w})$ composition of the photoprotective formulations

Tabela 1 - Composição Qualitativa e quantitativa (\% p/p) das formulações fotoprotectoras

\begin{tabular}{|c|c|c|c|c|c|c|c|c|c|c|c|c|c|c|c|c|}
\hline \multirow[b]{2}{*}{$\begin{array}{l}\text { Composition* } \\
\text { Composição** }\end{array}$} & \multicolumn{16}{|c|}{ Concentration $(\%$ w/w) / Concentração $(\% p / p)$} \\
\hline & F01 & F02 & F03 & F04 & F05 & F06 & F07 & F08 & F09 & F10 & F11 & F12 & F13 & F14 & F15 & F16 \\
\hline $\begin{array}{l}\text { Mangifera indica seed } \\
\text { (mango) butter (and) } \\
\text { dimethicone (and) ceteth-20 } \\
\text { (and) steareth-21 } \\
\text { indica manteiga de sementes } \\
\text { (manga) dimeticona (e) (e) } \\
\text { ceteth-20 (e) esteareto-21 }\end{array}$ & 1.5 & 1.5 & 1.5 & 1.5 & 1.5 & 1.5 & 1.5 & 1.5 & 1.5 & 1.5 & 1.5 & 1.5 & 1.5 & 1.5 & 1.5 & 1.5 \\
\hline $\begin{array}{l}\text { Butyrospermum parkii (shea } \\
\text { butter) (and) dimethicone } \\
\text { (and) ceteth-20 (and) } \\
\text { steareth-21 } \\
\text { (Manteiga de karité) } \\
\text { dimeticona (e) (e) ceteth-20 } \\
\text { (e) steareth-21 }\end{array}$ & 1.5 & 1.5 & 1.5 & 1.5 & 1.5 & 1.5 & 1.5 & 1.5 & 1.5 & 1.5 & 1.5 & 1.5 & 1.5 & 1.5 & 1.5 & 1.5 \\
\hline $\begin{array}{l}\text { Sodium polyacrylate (and) } \\
\text { dimethicone (and) } \\
\text { cyclopentasiloxane (and) } \\
\text { trideceth-6 (and) } \\
\text { PEG/PPG-18/18 } \\
\text { dimethicone } \\
\end{array}$ & 1.5 & 1.5 & 1.5 & 1.5 & 1.5 & 1.5 & 1.5 & 1.5 & 1.5 & 1.5 & 1.5 & 1.5 & 1.5 & 1.5 & 1.5 & 1.5 \\
\hline Alcohol Denat. & 15.0 & 15.0 & 15.0 & 15.0 & 15.0 & 15.0 & 15.0 & 15.0 & 15.0 & 15.0 & 15.0 & 15.0 & 15.0 & 15.0 & 15.0 & 15.0 \\
\hline $\begin{array}{l}\text { Sodium lauryl sulfate } \\
\text { Lauril sulfato de sódio }\end{array}$ & 0.5 & 0.5 & 0.5 & 0.5 & 0.5 & 0.5 & 0.5 & 0.5 & 0.5 & 0.5 & 0.5 & 0.5 & 0.5 & 0.5 & 0.5 & 0.5 \\
\hline BHT & 0.05 & 0.05 & 0.05 & 0.05 & 0.05 & 0.05 & 0.05 & 0.05 & 0.05 & 0.05 & 0.05 & 0.05 & 0.05 & 0.05 & 0.05 & 0.05 \\
\hline $\begin{array}{l}\text { Ammonium } \\
\text { acryloyldimethyltaurate/VP } \\
\text { copolymer } \\
\text { Copolimero de amônio } \\
\text { acryloyldimethyltaurate / VP }\end{array}$ & 3.0 & 3.0 & 3.0 & 3.0 & 3.0 & 3.0 & 3.0 & 3.0 & 3.0 & 3.0 & 3.0 & 3.0 & 3.0 & 3.0 & 3.0 & 3.0 \\
\hline $\begin{array}{l}\text { Propylene glycol } \\
\text { Propilenoglicol }\end{array}$ & 3.0 & 3.0 & 3.0 & 3.0 & 3.0 & 3.0 & 3.0 & 3.0 & 3.0 & 3.0 & 3.0 & 3.0 & 3.0 & 3.0 & 3.0 & 3.0 \\
\hline PEG-8 & 3.0 & 3.0 & 3.0 & 3.0 & 3.0 & 3.0 & 3.0 & 3.0 & 3.0 & 3.0 & 3.0 & 3.0 & 3.0 & 3.0 & 3.0 & 3.0 \\
\hline $\begin{array}{l}\text { Disodium EDTA } \\
\text { EDTA Dissódico }\end{array}$ & 0.05 & 0.05 & 0.05 & 0.05 & 0.05 & 0.05 & 0.05 & 0.05 & 0.05 & 0.05 & 0.05 & 0.05 & 0.05 & 0.05 & 0.05 & 0.05 \\
\hline $\begin{array}{l}\text { 2-Bromo-2-nitropropane- } \\
\text { 1,3-diol }\end{array}$ & 0.03 & 0.03 & 0.03 & 0.03 & 0.03 & 0.03 & 0.03 & 0.03 & 0.03 & 0.03 & 0.03 & 0.03 & 0.03 & 0.03 & 0.03 & 0.03 \\
\hline Aqua / Água & $* *$ & $* *$ & $* *$ & $* *$ & $* *$ & $* *$ & $* *$ & $* *$ & $* *$ & $* *$ & $* *$ & $* *$ & $* *$ & $* *$ & $* *$ & $* *$ \\
\hline Rutin / Rutina & 0.0 & 0.0 & 0.1 & 0.1 & 0.0 & 0.1 & 0.0 & 0.1 & 0.0 & 0.1 & 0.0 & 0.1 & 0.0 & 0.1 & 0.0 & 0.1 \\
\hline $\begin{array}{l}\text { Titanium dioxide } \\
\text { O dióxido de titânio }\end{array}$ & 2.0 & 2.0 & 2.0 & 1.0 & 1.0 & 1.0 & 2.0 & 1.0 & 1.0 & 1.0 & 1.0 & 2.0 & 1.0 & 2.0 & 2.0 & 2.0 \\
\hline $\begin{array}{l}\text { Benzophenone-3 (BZF) } \\
\text { Benzofenona-3 }(B Z F)\end{array}$ & 1.0 & 1.0 & 1.0 & 2.0 & 2.0 & 2.0 & 2.0 & 1.0 & 1.0 & 1.0 & 1.0 & 1.0 & 2.0 & 2.0 & 2.0 & 2.0 \\
\hline $\begin{array}{l}\text { Ethylhexyl } \\
\text { methoxycinnamate (EHM) } \\
\text { Etilhexil metoxicinamato } \\
(A E)\end{array}$ & 7.0 & 3.5 & 3.5 & 7.0 & 7.0 & 3.5 & 3.5 & 7.0 & 7.0 & 3.5 & 3.5 & 7.0 & 3.5 & 3.5 & 7.0 & 7.0 \\
\hline
\end{tabular}

* Qualitative composition was reported in accordance with INCI (International Nomenclature of Cosmetic Ingredient)

** Enough to complete 100\%

* composição qualitativa descrita segundo INCI (Nomenclatura Internacional de Ingredientes Cosméticos)

** Quantidade suficiente para $100 \%$

\section{Material and Methods}

\section{Formulations}

Sixteen emulsions were developed differing according to the concentration of the active compounds. Ethylhexyl methoxycinnamate (Uvinul ${ }^{\circledR}$ MC 80, Basf)

\section{Material e Métodos}

\section{Formulações}

Dezesseis emulsões, diferindo nas concentrações de compostos ativos, foram desenvolvidas. Etilhexil metoxicinamato (Uvinul ${ }^{\circledR}$ MC 80, Basf) e 
and Benzophenone-3 (Uvinul ${ }^{\circledR}$ MC 40, Basf) were selected as organic filters, Titanium dioxide $\left(\mathrm{TiO}_{2}\right.$ Henrifarma) as the inorganic filter and Rutin (Henrifarma) as the bioactive compound. The presence and associations among those four compounds was based on the factorial planning Design of Experiments (DOE) $2^{\mathrm{K}}$ in two levels. Analysis of the eventual combinations resulted in $2^{4}$ possible formulations. The formulation's qualitative and quantitative compositions are described in Table 1 .

\section{Preliminary Stability Testing}

The Preliminary Stability Testing was performed during the development phase of the formulations 24 hours after their preparation. It aimed at indicating the relative stability of the products and orienting the necessary adjustments to be performed on their composition ${ }^{[10]}$.

It was assessed using Centrifugation Testing and Thermical Stress Testing, in replicates of two. The centrifugation testing was performed at room temperature $\left(25.0^{\circ} \mathrm{C} \pm 2.0^{\circ} \mathrm{C}\right)$ with a $3000 \mathrm{rpm}$ rotation speed during 30 minutes. The Thermical Stress Testing was performed using a heating interval of $40-80^{\circ} \mathrm{C}$, with an increase of $10^{\circ} \mathrm{C} / 30 \mathrm{~min}$, and the formulations were then evaluated after reaching room temperature $\left(25.0^{\circ} \mathrm{C} \pm 2.0^{\circ} \mathrm{C}\right)$ for possible alterations concerning their aspect ${ }^{[10]}$. Only the products that remained stable under these conditions were submitted to the characterization.

\section{Formulations' Characterization}

\section{1 pH and rheological profile determination}

The $\mathrm{pH}$ values were determined in replicates of three using the $\mathrm{pH}$ meter (Quimis ${ }^{\circledR}$ ) by the introduction of the electrode in each sample followed by the reading after stabilization at room temperature $\left(25.0^{\circ} \mathrm{C} \pm 2.0^{\circ} \mathrm{C}\right)$. The rheological profile (flow curve) was obtained with the ViscoStar ${ }^{\circledR}$ viscosimeter equipped with a TR11 spindle. The flow curve was obtained by varying the rotation from 0.3 to $30 \mathrm{rpm}$ and then from 30 to 0.3 $\mathrm{rpm}$. The rotation was maintained in each level for 30 seconds to measure the apparent viscosity value (cP).

\subsection{In vitro photoprotective efficacy}

The photoprotective efficacy was assessed in vitro by quantifying the SPF value, UVA/UVB ratio and critical wavelength of the formulations, which were benzofenona-3 (Uvinul ${ }^{\circledR}$ MC 40, Basf) foram selecionados como filtros orgânicos, dióxido de titânio ( $\mathrm{TiO}_{2}$ Henrifarma) como filtro inorgânico e a rutina (Henrifarma) como composto bioativo. A presença e as associações desses quatro compostos foi baseada no projeto de planejamento fatorial de Experimentos (DOE) $2^{\mathrm{K}}$. A análise das possíveis combinações resultou em 24 formulações possíveis.

A composição quali e quantitativa $(\% \mathrm{p} / \mathrm{p})$ das formulações está descrita na Tabela 1.

\section{Teste de Estabilidade Preliminar}

O teste de estabilidade preliminar foi realizado durante a fase de desenvolvimento das formulações, 24 horas após a sua preparação. $O$ teste pretendeu indicar a relativa estabilidade dos produtos e orientar os ajustes necessários a serem executados em sua composição ${ }^{[10]}$. As formulações foram avaliadas por meio do Teste de Centrifugação e do Teste de Estresse térmico, em réplicas de dois. $\mathrm{O}$ ensaio de centrifugação foi realizado à temperatura ambiente $\left(25,0^{\circ} \mathrm{C} \pm 2,0^{\circ} \mathrm{C}\right)$ com velocidade de rotação de $3000 \mathrm{rpm}$ durante 30 minutos. O Teste de Estresse Térmico foi realizado em um intervalo de aquecimento de $40-80^{\circ} \mathrm{C}$, com um aumento de $10^{\circ} \mathrm{C} / 30 \mathrm{~min}$, e as formulações foram então avaliados, depois de atingir a temperatura ambiente $\left(25,0^{\circ} \mathrm{C} \pm 2,0^{\circ} \mathrm{C}\right)$, em relação a possíveis alterações de aspecto ${ }^{[10]}$. Apenas os produtos que se mantiveram estáveis, nestas condições, foram submetidos à caracterização.

\section{Caracterização das Formulações}

\subsection{Determinação do valor de pH e perfil reológico}

Os valores de $\mathrm{pH}$ foram determinados, em réplicas de três, usando o pHmetro (Quimis ${ }^{\circledR}$ ) pela introdução direta do eletrodo em cada amostra, seguido pela leitura após a estabilização, à temperatura ambiente $\left(25,0^{\circ} \mathrm{C} \pm 2,0^{\circ} \mathrm{C}\right)$.

O perfil reológico (curva de fluxo) foi obtido com o viscosímetro ViscoStar ${ }^{\circledR}$ equipado com agulha TR11. A curva de fluxo foi obtida através da variação da rotação 0,3-30 rpm e, em seguida, 30-0,3 rpm. A rotação foi mantida por um período de 30 segundos para medir o valor da viscosidade aparente $(\mathrm{cP})$.

\subsection{Eficácia fotoprotetora in vitro}

A eficácia fotoprotetora in vitro foi avaliada por quantificação do valor FPS, razão UVA / UVB e comprimento de comprimento de onda crítico das 
measured by reflectance spectrophotometry with integrated sphere (Labsphere ${ }^{\circledR}$ UV-2000S Ultraviolet Transmittance Analyzer). The transmittance values are registered with a wavelength interval of $250-450 \mathrm{~nm}$ with a progression of $1 \mathrm{~nm}$. The samples were accurately weighted and uniformly applied with a glove-coated finger on the rough side of PMMA (poly methyl methacrylate) plates in the ratio of 0.75 $\mathrm{mg} / \mathrm{cm}^{2}$. The samples were then allowed to dry at room temperature during 25 minutes protected from the light $[8 ; 11 ; 12]$. The plates were prepared in replicates of two, and nine different points per plate were measured for each sample.

\subsection{Antioxidant activity}

Antioxidant activity of the formulations was determined using samples of equal concentration in the presence of 2,2-diphenyl-1-picrylhydrazyl (DPPH) solution in comparison with solutions of free-rutin (F17). The spectrophotometric readings were obtained using ethanolic solutions of samples and $100,0 \mu \mathrm{M}$ DPPH solution (Sigma) at a ratio of 1:7, after 20 minutes of reaction at room temperature $\left(24.0+2.0^{\circ} \mathrm{C}\right)$. All the samples were prepared and analyzed in triplicate. The absorbance values were measured at $515,0 \mathrm{~nm} 515.0 \mathrm{~nm}$ and converted into the percentage of free radical scavenging using the following formula ${ }^{1[13 ; 14]}$.

$$
\% \mathbf{F R S}=\mathbf{1 0 0}-\left\{\left[\left(\mathrm{Abs}_{\text {control }}-\mathbf{A b s}_{\text {sample }}\right) \times 100\right] / \mathbf{A b s}_{\text {control }}\right\}
$$

Equation 1. Determination of percentage of free radical scavenging. Legend: \% FRS: Percentage of free radical scavenging; $\mathbf{A b s}_{\text {control: }}$ Absorbance of negative control sample; Abs $_{\text {sample: }}$ Absorbance of samples.

\section{Testing}

Only the formulation with the best photoprotective result was submitted to Normal Stability Testing as well as the correspondent formulation without rutin. The aim of this test was to verify the influence of rutin on the formulation's physicochemical and functional stability.

The samples were stored in opaque white polyethylene tubes under the following environmental conditions: (I) $40.0^{\circ} \mathrm{C} \pm 0.5^{\circ} \mathrm{C}$; (ii) room temperature at $25.0^{\circ} \mathrm{C} \pm$ $2.0^{\circ} \mathrm{C}$ under direct and indirect sunlight exposure; (iii) $5.0^{\circ} \mathrm{C} \pm 0.5^{\circ} \mathrm{C}$. The organoleptical characteristics (color, odor and aspect), $\mathrm{pH}$, antioxidant activity and formulações, as quais foram medidos pelo espectrofotômetro de refletância com esfera de integração (Labsphere ${ }^{\circledR}$ UV-2000S Analyzer Transmitância Ultravioleta). Os valores de transmitância foram obtidos em um intervalo de comprimento de onda de 250-450 nm, com registros a cada um nm. As amostras foram pesadas com precisão e uniformemente aplicadas com o dedo, revestido por luva, sobre o lado áspero de placas de PMMA (poli metacrilato de metila) na razão de $0,75 \mathrm{mg} / \mathrm{cm}^{2}$. As amostras foram, em seguida, deixadas secar a temperatura ambiente durante 25 minutos protegidos da luz ${ }^{[8 ; 11 ; 12]}$. As placas foram preparadas em replicas de dois, e nove pontos diferentes por placa foram medidos para cada amostra.

\subsection{Atividade Antirradicalar}

A atividade antirradicalar das formulações foi determinada usando as amostras na mesma concentração, na presença da solução de 2,2-difenil-1picrilhidrazil (DPPH), em comparação com soluções de rutina livre (F17). As leituras espectrofotométricas foram obtidas usando soluções etanólicas das amostras e uma solução de 100,0 $\mu \mathrm{M}$ de DPPH (2,2-difenil-1picrilhidrazil, Sigma) a uma razão de 1:7, após 20 minutos de reação à temperatura ambiente $(24,0+$ $\left.2,0^{\circ} \mathrm{C}\right)$. Todas as amostras foram preparadas $\mathrm{e}$ analisadas em triplicata. Os valores de absorbância foram medidos em $515,0 \mathrm{~nm}$, e convertidos na percentagem de sequestro de radicais livres (\%SRL) usando a equação $1^{[13 ; 14]}$.

$$
\% \mathrm{SRL}=\left[\left(\mathrm{Abs}_{\text {controle }}-\mathrm{Abs}_{\text {amostra }}\right) \times 100\right] / \mathrm{Abs}_{\text {controle }}
$$

Equação 1. Equação determinante da porcentagem de sequestro de radicais livres. Legenda: \% SRL: Porcentagem de radicais livres sequestrados; Abs controle $_{\text {: }}$ Absorbância da amostra controle negativo; Abs $_{\text {amostra }}$ : Absorbância das amostras

\section{Testes}

Apenas a melhor formulação fotoprotetora foi submetida ao teste de estabilidade normal, bem como a formulação correspondente sem rutina. $\mathrm{O}$ objetivo deste ensaio foi verificar a influência da rutina sobre a estabilidade físico-química e funcional da formulação. As amostras foram armazenadas em bisnagas brancas de polietileno opaco nas seguintes condições: (i) $40,0^{\circ} \mathrm{C} \pm 0,5^{\circ} \mathrm{C}$, (ii) temperatura ambiente a $25,0^{\circ} \mathrm{C} \pm$ $2,0^{\circ} \mathrm{C}$ sob exposição à luz solar direta e indireta; (iii) $5,0^{\circ} \mathrm{C} \pm 0,5^{\circ} \mathrm{C}$. As características organolépticas (odor, cor e aspecto), valor de $\mathrm{pH}$, atividade antirradicalar e perfil reológico foram avaliados em T0 (48h após a 
rheological profile were assessed on t0 (48h after product preparation, defined as non-alteration reference) and on the $15^{\text {th }}, 30^{\text {th }}$ and $60^{\text {th }}$ days. The in vitro photoprotective efficacy was assessed on $\mathrm{t} 0(48 \mathrm{~h}$ after product preparation, defined as non-alteration reference) and on the $30^{\text {th }}$ and $60^{\text {th }}$ days ${ }^{[15]}$.

\section{Results}

\section{Preliminary Stability Testing}

All formulations remained unaltered during the Thermical Stress Testing and all demonstrated expected slight alterations in the Centrifugation Testing - appearance of a thin transparent liquid layer on the surface. None of the alterations were considered as significant instability signs due to the drastic test conditions adopted. Therefore, no formulation that presented such signs was eliminated from the study.

\section{Formulations' Characterization}

The 16 formulations presented $\mathrm{pH}$ values compatible with human skin $(4.5-6.5)$ thus being considered as adequate. Table 2 presents the average of the measured $\mathrm{pH}$ values. preparação do produto, definido como alteração nãoreferência) e no dia 15 , dias 30 e 60 . A eficácia in vitro fotoprotector foi avaliada em t0 (48h após a preparação do produto, definida como referência de não alteração) e nos dias 30 e $60^{[15] .}$

\section{Resultados}

\section{Teste de Estabilidade Preliminar}

Todas as formulações permaneceram inalteradas durante o Teste de Estresse Térmico e todas demonstraram ligeiras alterações no Teste de Centrifugação - aparecimento de uma fina camada de líquido transparente sobre a superfície. Nenhuma das alterações foram considerados como sinais de instabilidade significativa devido às condições drásticas adotadas no ensaio. Portanto, nenhuma formulação que apresentou tais sinais foi eliminada do estudo.

\section{Caracterização de Formulações}

As 16 formulações apresentaram valores de $\mathrm{pH}$ compatíveis com a pele humana $(4,5-6,5)$ sendo assim, consideradas como adequadas. A Tabela 2 descreve a média dos valores de $\mathrm{pH}$.

Table 2 - Average $\mathrm{pH}$ values

Tabela 2 - Média de valores de $\mathrm{pH}$

\begin{tabular}{ccccccccc}
\hline $\begin{array}{c}\text { Formulation } \\
\text { Formulação }\end{array}$ & $\mathbf{F 0 1}$ & $\mathbf{F 0 2}$ & $\mathbf{F 0 3}$ & $\mathbf{F 0 4}$ & $\mathbf{F 0 5}$ & $\mathbf{F 0 6}$ & $\mathbf{F 0 7}$ & $\mathbf{F 0 8}$ \\
$\begin{array}{c}\text { pH } \\
\begin{array}{c}\text { Formulation } \\
\text { Formulação }\end{array}\end{array}$ & 6,4 & 6,1 & 5,8 & 6,4 & 6,4 & 6,3 & 6,4 & 6,3 \\
$\mathbf{p H}$ & 6,3 & $\mathbf{F 1 0}$ & $\mathbf{F 1 1}$ & $\mathbf{F 1 2}$ & $\mathbf{F 1 3}$ & $\mathbf{F 1 4}$ & $\mathbf{F 1 5}$ & $\mathbf{F 1 6}$ \\
\hline
\end{tabular}

The rheological profile determination demonstrated that all formulations presented similar behavior. They were classified as non-Newtonian and thixotropic due to the presence of a hysteresis area. Rutin reduced the formulation viscosity in 14\% when associated with all filters on their lowest concentrations. It also increased in $37 \%$ the viscosity of the formulation containing $\mathrm{TiO}_{2}$ on the highest and chemical filters on their lowest
A determinação do perfil reológico demonstrou que todas as formulações apresentaram comportamento semelhante. Elas foram classificadas como nãoNewtonianas e tixotrópicas, devido à presença de uma área de histerese. A rutina reduziu a viscosidade da formulação em $14 \%$ quando associado a todos os filtros em suas concentrações mais baixas. Além disso, aumentou em $37 \%$ a viscosidade da formulação 
concentration when compared to the same formulation without rutin. However, it did not influence the viscosity of the formulations containing only chemical filters on their highest concentrations (data not shown). Table 3 presents the percentage of free radical scavenging of formulations and free-rutin solution (F17). contendo $\mathrm{TiO}_{2}$ na máxima concentração, associado a filtros químicos em sua concentração mínima, quando comparado com a mesma formulação, sem rutina. No entanto, não influenciou a viscosidade das formulações contendo apenas filtros apenas químicos nas concentrações máximas (dados não mostrados). A Tabela 3 descreve a porcentagem de sequestro de radicais livres das formulações e da solução etanólica de rutina $(\mathbf{F 1 7})$.

Table 3 - Percentage of free radical scavenging (FRS)

Tabela 3 - Percenagem de sequestro de radicais livres

\begin{tabular}{|c|c|c|c|c|c|}
\hline \multirow[t]{2}{*}{$\begin{array}{l}\text { Formulations } \\
\text { Formulações }\end{array}$} & \multicolumn{4}{|c|}{$\begin{array}{l}\text { Active Compounds / Compostos Ativos } \\
\text { Concentration }(\% \mathbf{w} / \mathbf{w}) \text { Concentração }(\% p / p)\end{array}$} & \multirow[t]{2}{*}{$\begin{array}{l}\% \text { FRS } \\
\% \text { SRL }\end{array}$} \\
\hline & Rutin & ЕНM & BZF & $\mathrm{TiO}_{2}$ & \\
\hline F01 & 0,0 & 7,0 & 1,0 & 2,0 & 2,3 \\
\hline F02 & 0,0 & 3,5 & 1,0 & 2,0 & 0,1 \\
\hline F03 & 0,1 & 3,5 & 1,0 & 2,0 & 33,7 \\
\hline F04 & 0,1 & 7,0 & 2,0 & 1,0 & 37,6 \\
\hline F05 & 0,0 & 7,0 & 2,0 & 1,0 & 1,2 \\
\hline F06 & 0,1 & 3,5 & 2,0 & 1,0 & 45,2 \\
\hline F07 & 0,0 & 3,5 & 2,0 & 2,0 & 0,2 \\
\hline F08 & 0,1 & 7,0 & 1,0 & 1,0 & 49,1 \\
\hline F09 & 0,0 & 7,0 & 1,0 & 1,0 & $-0,3$ \\
\hline F10 & 0,1 & 3,5 & 1,0 & 1,0 & 29,9 \\
\hline F11 & 0,0 & 3,5 & 1,0 & 1,0 & $-0,1$ \\
\hline F12 & 0,1 & 7,0 & 1,0 & 2,0 & 11,7 \\
\hline F13 & 0,0 & 3,5 & 2,0 & 1,0 & $-0,6$ \\
\hline F14 & 0,1 & 3,5 & 2,0 & 2,0 & 34,1 \\
\hline F15 & 0,0 & 7,0 & 2,0 & 2,0 & $-0,9$ \\
\hline F16 & 0,1 & 7,0 & 2,0 & 2,0 & 33,3 \\
\hline F17 & 0,1 & 0,0 & 0,0 & 0,0 & 32,2 \\
\hline
\end{tabular}

Formulations of better performance with respect to values of antioxidant activity were the F06 and F08, that presented $\% \mathrm{FRS}$ equal to $45,2 \%$ e $49,1 \%$, respectively. In relation to the increase of antirradicalar activity of rutin, it was found that the ideal formulation should have just one of the chemical filters in the maximum concentration and that the inorganic filter should be in the minimal concentration.
As formulações de melhor desempenho no que diz respeito aos valores de atividade antirradicalar foram as formulações F06 e F08, que apresentaram \%SRL igual a $45,2 \%$ e $49,1 \%$, respectivamente. Em relação ao aumento da atividade antirradicalar da rutina, verificou-se que a formulação ideal deverá ter apenas um dos filtros químicos na concentração máxima e que o filtro inorgânico deve estar na concentração mínima. 
In agreement with the statistical analysis (Statistica ${ }^{\circledR} 9 \mathrm{e}$ Minitab $\left.^{\circledR} 16\right)$, the in vitro photoprotective efficacy assessment demonstrated in F16 $(\mathrm{p}<0.05)$ was the highest SPF result (data not shown) and it was therefore chosen for the Normal Stability Testing as well as the same formulation without rutin. This result is coherent as the formulation with the highest quantity of filters presented the best photoprotective efficacy.

\section{Normal Stability Testing}

Tables 4, 5, 6, 7 and 8 represent, respectively, the organoleptical characteristics, $\mathrm{pH}$, antioxidant activity, viscosity and in vitro photoprotective efficacy results.
De acordo com a análise estatística (softwares Statistica ${ }^{\circledR} 9$ e Minitab $\left.^{\circledR} 16\right)$, a avaliação da eficácia fotoprotetora in vitro demonstrou que a formulação F16 $(\mathrm{p}<0,05)$ apresentou o valor do FPS foi mais elevado (dados não mostrados) e foi, por conseguinte, foi escolhida para os Testes de Estabilidade Normal, bem como a mesma formulação sem rutina. Este resultado é coerente, uma vez que a formulação com a maior quantidade de filtros apresentou o melhor eficácia fotoprotetora.

\section{Testes de Estabilidade Normal}

As Tabelas 4, 5, 6, 7 e 8 representam, respectivamente, as características organolépticas, valor de $\mathrm{pH}$, atividade antirradicalar, viscosidade e eficácia fotoprotetora in vitro.

Table 4 - Organoleptical characteristics of the formulations $48 \mathrm{~h}$ after preparation ( 0 ) and on the 15th, 30th and 60 th day of analysis (t15, t30 and t60 respectively) under the defined storage conditions

Tabela 4 - Características organolépticas das formulações 48 horas após a preparação (t0) e no dia 15, 30 e 60 de análises (t15, t30 e t60, respectivamente), sob as condições de armazenamento definidas

\begin{tabular}{|c|c|c|c|c|c|c|c|c|c|c|}
\hline \multirow[b]{2}{*}{$\begin{array}{c}\text { Formulation } \\
\text { Formulação }\end{array}$} & \multirow[b]{2}{*}{$\begin{array}{l}\text { Parameter } \\
\text { Parâmetro }\end{array}$} & \multicolumn{3}{|c|}{ t15 } & \multicolumn{3}{|c|}{ t30 } & \multicolumn{3}{|c|}{ t60 } \\
\hline & & $\begin{array}{c}\text { Room } \\
\text { temperature } \\
\text { Temperatura } \\
\text { Ambiente }\end{array}$ & $\begin{array}{c}40.0^{\circ} \\
\mathrm{C} \pm \\
0.5^{\circ} \mathrm{C}\end{array}$ & $\begin{array}{l}5.0^{\circ} \mathrm{C} \\
\pm \\
0.5^{\circ} \mathrm{C}\end{array}$ & $\begin{array}{c}\text { Room } \\
\text { temperature } \\
\text { Temperatura } \\
\text { Ambiente }\end{array}$ & $\begin{array}{c}40.0^{\circ} \\
\mathrm{C} \pm \\
0.5^{\circ} \mathrm{C}\end{array}$ & $\begin{array}{l}5.0^{\circ} \mathrm{C} \\
\pm \\
0.5^{\circ} \mathrm{C}\end{array}$ & $\begin{array}{c}\text { Room } \\
\text { temperature } \\
\text { Temperatura } \\
\text { Ambiente }\end{array}$ & $\begin{array}{c}40.0^{\circ} \\
\mathrm{C} \pm \\
0.5^{\circ} \mathrm{C}\end{array}$ & $\begin{array}{l}5.0^{\circ} \mathrm{C} \\
\pm \\
0.5^{\circ} \mathrm{C}\end{array}$ \\
\hline \multirow{3}{*}{$\begin{array}{l}\text { With rutin } \\
\text { Com Rutina }\end{array}$} & Aspect & $\mathrm{N}$ & $\mathrm{N}$ & $\mathrm{N}$ & $\mathrm{N}$ & SM & $\mathrm{N}$ & $\mathrm{N}$ & $\mathrm{SM}$ & $\mathrm{N}$ \\
\hline & Color & $\mathrm{N}$ & $\mathrm{N}$ & $\mathrm{N}$ & SM & M & $\mathrm{N}$ & M & M & $\mathrm{N}$ \\
\hline & Odor & $\mathrm{N}$ & $\mathrm{N}$ & $\mathrm{N}$ & $\mathrm{N}$ & $\mathrm{N}$ & $\mathrm{N}$ & $\mathrm{N}$ & SM & $\mathrm{N}$ \\
\hline \multirow{3}{*}{$\begin{array}{l}\text { Without rutin } \\
\text { Sem Rutina }\end{array}$} & Aspect & $\mathrm{N}$ & $\mathrm{N}$ & $\mathrm{N}$ & $\mathrm{N}$ & $\mathrm{N}$ & $\mathrm{N}$ & $\mathrm{N}$ & $\mathrm{N}$ & $\mathrm{N}$ \\
\hline & Color & $\mathrm{N}$ & $\mathrm{N}$ & $\mathrm{N}$ & $\mathrm{N}$ & SM & $\mathrm{N}$ & M & M & $\mathrm{N}$ \\
\hline & Odor & $\mathrm{N}$ & $\mathrm{N}$ & $\mathrm{N}$ & $\mathrm{N}$ & $\mathrm{N}$ & $\mathrm{N}$ & $\mathrm{N}$ & $\mathrm{SM}$ & $\mathrm{N}$ \\
\hline
\end{tabular}

\begin{tabular}{|c|c|c|c|}
\hline \multicolumn{2}{|c|}{$\begin{array}{c}\text { Day / Storage Condition } \\
\text { Dia / Condição Armazenamento }\end{array}$} & \multicolumn{2}{|c|}{ Formulation / Formulação } \\
\hline & & $\begin{array}{l}\text { With rutin } \\
\text { Com Rutina }\end{array}$ & $\begin{array}{l}\text { Without rutin } \\
\text { Sem Rutina }\end{array}$ \\
\hline & to & $7.56 \pm 0.01$ & $6.43 \pm 0.03$ \\
\hline \multirow{3}{*}{$\mathbf{t 1 5}$} & $\begin{array}{l}\text { Room temperature } \\
\text { Temperatura Ambiente }\end{array}$ & $7.09 \pm 0.10$ & $6.31 \pm 0.14$ \\
\hline & $40.0^{\circ} \mathrm{C} \pm 0.5^{\circ} \mathrm{C}$ & $6.48 \pm 0.06$ & $6.01 \pm 0.05$ \\
\hline & $5.0^{\circ} \mathrm{C} \pm 0.5^{\circ} \mathrm{C}$ & $7.23 \pm 0.10$ & $6.28 \pm 0.05$ \\
\hline \multirow{3}{*}{ t30 } & $\begin{array}{l}\text { Room temperature } \\
\text { Temperatura Ambiente }\end{array}$ & $7.09 \pm 0.09$ & $6.27 \pm 0.04$ \\
\hline & $40.0^{\circ} \mathrm{C} \pm 0.5^{\circ} \mathrm{C}$ & $6.4 \pm 0.04$ & $5.96 \pm 0.05$ \\
\hline & $5.0^{\circ} \mathrm{C} \pm 0.5^{\circ} \mathrm{C}$ & $7.57 \pm 0.19$ & $6.32 \pm 0.02$ \\
\hline \multirow{3}{*}{ t60 } & $\begin{array}{l}\text { Room temperature } \\
\text { Temperatura Ambiente }\end{array}$ & $6.59 \pm 0.03$ & $6.16 \pm 0.04$ \\
\hline & $40.0^{\circ} \mathrm{C} \pm 0.5^{\circ} \mathrm{C}$ & $6.35 \pm 0.05$ & $5.79 \pm 0.03$ \\
\hline & $5.0^{\circ} \mathrm{C} \pm 0.5^{\circ} \mathrm{C}$ & $7.21 \pm 0.06$ & $6.36 \pm 0.06$ \\
\hline
\end{tabular}

Table 5 - $\mathrm{pH}$ values of the formulations $48 \mathrm{~h}$ after preparation $(\mathrm{t} 0)$ and on the $15 \mathrm{th}, 30$ th and 60th day of analysis (t15, t30 and t60 respectively) under the defined storage conditions

Tabela 5 - valores de $\mathrm{pH}$ das formulações 48 horas após a preparação (t0) e no dia 15,30 e 60 de análise (t15, t30 e t60, respectivamente), sob as condições de armazenamento definidas 


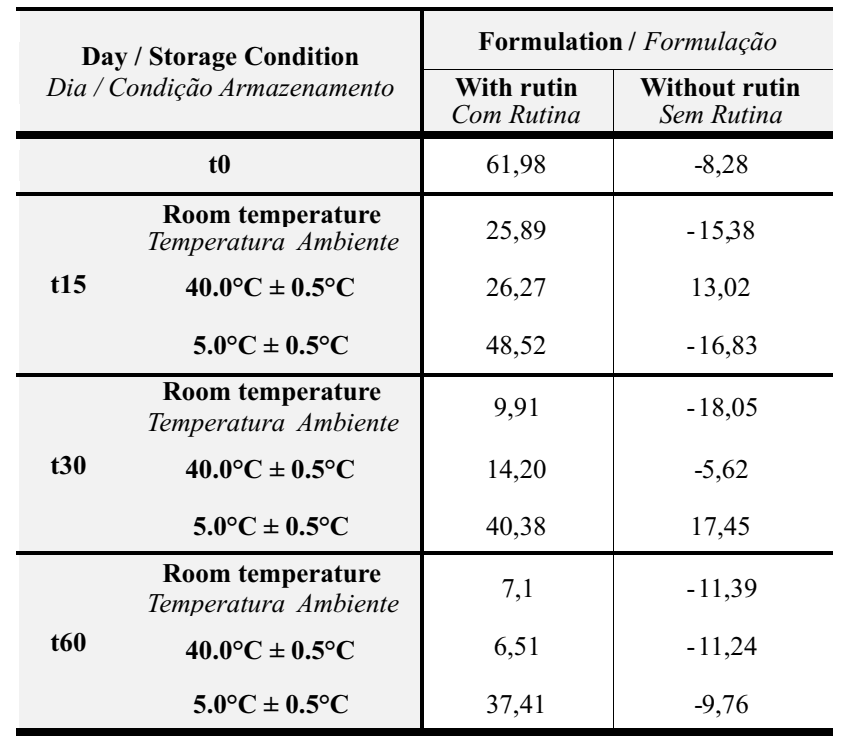

\begin{tabular}{ccc}
\hline \multicolumn{3}{c}{ Viscosity (cP) - t0 / Viscosidade $(c P)$ - $t 0$} \\
\hline Rotations (RPM) & Without rutin & With rutin \\
Rotações (rpm) & Sem Rutina & Com Rutina \\
\hline 0.3 & 1292400 & 1933100 \\
1.0 & 723500 & 858800 \\
2.5 & 326000 & 348400 \\
5.0 & 178100 & 176400 \\
5.0 & 159700 & 146600 \\
2.5 & 295000 & 221500 \\
1.0 & 568000 & 482900 \\
0.3 & 1132300 & 1079900 \\
\hline
\end{tabular}

Table 6 - Percentage of free radical scavenging of the formulations $48 \mathrm{~h}$ after preparation (t0) and on the 15th, 30 th and 60th day of analysis (t15, t30 and t60 respectively) under the defined storage conditions

Tabela 6 - Percentual de sequestro de radicais livres $48 \mathrm{~h}$ após o preparo (T0) e no décimo quinto, trigésimo, e sexagésimo dias de análises (T15, T30 e T60 respectivamente) sob as condições de armazenamento definidas

\begin{tabular}{|c|c|c|c|c|c|c|}
\hline \multicolumn{7}{|c|}{ Viscosity (cP) - t15 days / Viscosidade (cP) - T15 dia } \\
\hline \multirow{2}{*}{$\begin{array}{c}\text { Rotations } \\
\text { Rotações } \\
\text { (RPM) }\end{array}$} & \multicolumn{2}{|c|}{$\begin{array}{c}\text { Room temperature } \\
\text { Temperatura ambiente }\end{array}$} & \multicolumn{2}{|c|}{$40.0^{\circ} \mathrm{C} \pm 0.5^{\circ} \mathrm{C}$} & \multicolumn{2}{|c|}{$5.0^{\circ} \mathrm{C} \pm 0.5^{\circ} \mathrm{C}$} \\
\hline & $\begin{array}{c}\text { Without rutin } \\
\text { Sem Rutina }\end{array}$ & $\begin{array}{l}\text { With rutin } \\
\text { Com Rutina }\end{array}$ & $\begin{array}{l}\text { Without rutin } \\
\text { Sem Rutina }\end{array}$ & $\begin{array}{l}\text { With rutin } \\
\text { Com Rutina }\end{array}$ & $\begin{array}{l}\text { Without rutin } \\
\text { Sem Rutina }\end{array}$ & $\begin{array}{l}\text { With rutin } \\
\text { Com Rutina }\end{array}$ \\
\hline 0.3 & 1115100 & 2688000 & 2401000 & 2260200 & 2245300 & 2274000 \\
\hline 1.0 & 654700 & 933100 & 799400 & 858600 & 810000 & 857700 \\
\hline 2.5 & 310300 & / & 358100 & 374300 & 363700 & 327500 \\
\hline 5.0 & 164700 & / & 198500 & l & / & 147800 \\
\hline 5.0 & 132400 & / & 195800 & 181500 & 192300 & 66800 \\
\hline 2.5 & 225500 & 364400 & 349900 & 322400 & 342300 & 135700 \\
\hline 1.0 & 486700 & 797700 & 768100 & 708300 & 742700 & 327200 \\
\hline 0.3 & 1025000 & 2102200 & 2165400 & 1805000 & 2061900 & 952500 \\
\hline
\end{tabular}

Table 7* - Viscosity values (cP) of the formulations $48 \mathrm{~h}$ after preparation ( $\mathrm{t} 0$ ) and on the 15th, 30th and 60th day of analysis (t15, t30 and t60 respectively), under the defined storage conditions, for each rotation speed

Tabela $7 *$ - Valores de viscosidade em (cP) das formulações $48 \mathrm{~h}$ após o preparo (T0) e no décimo quinto, trigésimo, e sexagésimo dias de análises (T15, T30 e T60 respectivamente) sob as condições de armazenamento definidas 


\begin{tabular}{|c|c|c|c|c|c|c|}
\hline \multicolumn{7}{|c|}{ Viscosity (cP) - t30 days / Viscosidade $(c P)-T 30$ dia } \\
\hline \multirow{2}{*}{$\begin{array}{c}\text { Rotations } \\
\text { Rotações } \\
\text { (RPM) }\end{array}$} & \multicolumn{2}{|c|}{$\begin{array}{l}\text { Room temperature } \\
\text { Temperatura ambiente }\end{array}$} & \multicolumn{2}{|c|}{$40.0^{\circ} \mathrm{C} \pm 0.5^{\circ} \mathrm{C}$} & \multicolumn{2}{|c|}{$5.0^{\circ} \mathrm{C} \pm 0.5^{\circ} \mathrm{C}$} \\
\hline & $\begin{array}{c}\text { Without rutin } \\
\text { Sem Rutina } \\
\end{array}$ & $\begin{array}{l}\text { With rutin } \\
\text { Com Rutina }\end{array}$ & $\begin{array}{l}\text { Without rutin } \\
\text { Sem Rutina }\end{array}$ & $\begin{array}{l}\text { With rutin } \\
\text { Com Rutina }\end{array}$ & $\begin{array}{l}\text { Without rutin } \\
\text { Sem Rutina }\end{array}$ & $\begin{array}{l}\text { With rutin } \\
\text { Com Rutina }\end{array}$ \\
\hline 0.3 & 1334200 & 2602600 & 2332800 & 2868800 & 2432800 & 2584300 \\
\hline 1.0 & 675900 & 831500 & 798200 & 870500 & 833700 & 862400 \\
\hline 2.5 & 338200 & 343700 & 356200 & 385400 & 372600 & 377200 \\
\hline 5.0 & 186700 & 189100 & 196300 & l & l & / \\
\hline 5.0 & 171700 & / & 191800 & l & / & l \\
\hline 2.5 & 305500 & 347200 & 342400 & l & 369800 & 355800 \\
\hline 1.0 & 634900 & 791600 & 755400 & 888200 & 817800 & 792700 \\
\hline 0.3 & 1461100 & 2363900 & 2197800 & 2589500 & 2406700 & 2362700 \\
\hline \multicolumn{7}{|c|}{ Viscosity (cP) - t60 days / Viscosidade (cP) - T60 dia } \\
\hline \multirow{2}{*}{$\begin{array}{c}\text { Rotations } \\
\text { Rotações } \\
\text { (RPM) }\end{array}$} & \multicolumn{2}{|c|}{$\begin{array}{c}\text { Room temperature } \\
\text { Temperatura ambiente }\end{array}$} & \multicolumn{2}{|c|}{$40.0^{\circ} \mathrm{C} \pm 0.5^{\circ} \mathrm{C}$} & \multicolumn{2}{|c|}{$5.0^{\circ} \mathrm{C} \pm 0.5^{\circ} \mathrm{C}$} \\
\hline & $\begin{array}{l}\text { Without rutin } \\
\text { Sem Rutina } \\
\end{array}$ & $\begin{array}{l}\text { With rutin } \\
\text { Com Rutina }\end{array}$ & $\begin{array}{l}\text { Without rutin } \\
\text { Sem Rutina } \\
\end{array}$ & $\begin{array}{l}\text { With rutin } \\
\text { Com Rutina }\end{array}$ & $\begin{array}{c}\text { Without rutin } \\
\text { Sem Rutina } \\
\end{array}$ & $\begin{array}{l}\text { With rutin } \\
\text { Com Rutina }\end{array}$ \\
\hline 0.3 & 1211300 & 1278600 & 2379900 & 2208500 & 2033400 & 1856400 \\
\hline 1.0 & 496300 & 495300 & 787000 & 867900 & 745100 & 564000 \\
\hline 2.5 & 226300 & 219200 & 358500 & 348600 & 329300 & 266600 \\
\hline 5.0 & 125400 & 101100 & 198300 & 191600 & 181300 & 159500 \\
\hline 5.0 & 134100 & 80800 & 198600 & 192500 & 155000 & 127600 \\
\hline 2.5 & 239200 & 153800 & 358500 & 340200 & 290000 & 251800 \\
\hline 1.0 & 552200 & 437700 & 799000 & 749800 & 665400 & 595000 \\
\hline 0.3 & 1615200 & 1341100 & 2362600 & 2163800 & 2037800 & 1806200 \\
\hline
\end{tabular}

Table 8 - In vitro photoprotective efficacy results of the formulations $48 \mathrm{~h}$ after preparation (t0) and on the 30 th and 60 th day of analysis ( $\mathrm{t} 30$ and $\mathrm{t} 60$ respectively) under the defined storage conditions

Tabela 8 - Eficácia fotoprotetora in vitro 48h após o preparo (T0) e trigésimo e sexagésimo dias de análises (T30 e T60 respectivamente) sob as condições de armazenamento definidas

\begin{tabular}{|c|c|c|c|c|c|c|c|c|}
\hline \multirow[b]{2}{*}{$\begin{array}{l}\text { Formulation } \\
\text { Formulação }\end{array}$} & \multirow[b]{2}{*}{$\begin{array}{l}\text { Parameter } \\
\text { Parâmetro }\end{array}$} & \multirow[b]{2}{*}{ to } & \multicolumn{3}{|c|}{ t30 } & \multicolumn{3}{|c|}{ t60 } \\
\hline & & & $\begin{array}{l}\text { Room temperature } \\
\text { Temperatura ambiente }\end{array}$ & $\begin{array}{c}40.0^{\circ} \mathrm{C} \pm \\
0.5^{\circ} \mathrm{C}\end{array}$ & $\begin{array}{c}5.0^{\circ} \mathrm{C} \pm \\
0.5^{\circ} \mathrm{C}\end{array}$ & $\begin{array}{l}\text { Room temperature } \\
\text { Temperatura ambiente }\end{array}$ & $\begin{array}{c}40.0^{\circ} \mathrm{C} \pm \\
0.5^{\circ} \mathrm{C}\end{array}$ & $\begin{array}{c}5.0^{\circ} \mathrm{C} \pm \\
0.5^{\circ} \mathrm{C}\end{array}$ \\
\hline \multirow{3}{*}{$\begin{array}{l}\text { With Rutin } \\
\text { Com Rutina }\end{array}$} & Mean SPF (média de SPF) & 4,5 & 4,0 & 4,0 & 4,0 & 4,5 & 4,5 & 5,0 \\
\hline & $\begin{array}{c}\text { Critical wavelength } \\
\text { (without irradiation) } \\
\text { Comprimento de onda critica } \\
\text { (Sem irradiação) }\end{array}$ & 370 & 370 & 369,5 & 368 & 370 & 368,5 & 371,5 \\
\hline & $\begin{array}{l}\text { UVA/UVB ratio } \\
\text { UVA / UVB relação }\end{array}$ & 0,50 & 0,55 & 0,50 & 0,48 & 0,45 & 0,46 & 0,49 \\
\hline \multirow{3}{*}{$\begin{array}{l}\text { Without Rutin } \\
\text { Sem Rutina }\end{array}$} & Mean SPF (média de SPF) & 4,0 & 4,0 & 3,0 & 3,0 & 4,5 & 4,0 & 4,0 \\
\hline & $\begin{array}{c}\text { Critical wavelength } \\
\text { (without irradiation) } \\
\text { Comprimento de onda crítica } \\
\text { (Sem irradiação) }\end{array}$ & 367 & 368 & 367 & 367,5 & 366,5 & 367 & 369,5 \\
\hline & $\begin{array}{l}\text { UVA/UVB ratio } \\
U V A / U V B \text { relação }\end{array}$ & 0,46 & 0,48 & 0,47 & 0,47 & 0,43 & 0,44 & 0,46 \\
\hline
\end{tabular}

The analysis was performed in duplicates with 9 reading points per plate. The results are represented as the mean for each plate.

A análise foi realizada em duplicado com 9 pontos de leitura por placa. Os resultados estão representados como a média para cada placa. 


\section{Discussion}

The formulations containing rutin tended to present slightly higher $\mathrm{pH}$ values throughout the stability testing. Both formulations' $\mathrm{pH}$ values were stable during the 60 days under the adopted experimental conditions and were compatible with the physiologic $\mathrm{pH}$ of human skin.

In relation to the antioxidant activity, values of the percentage of free radical scavenging were high for formulations containing rutin, as expected. It was noted that there was some decay of the antioxidant activity in the samples containing rutin over time, but the samples of the condition $5.0 \pm 0.5^{\circ} \mathrm{C}$ remained more stable as regards the antioxidant activity. In the storage conditions of $24.0 \pm 2.0$ and $40.0 \pm 0.5^{\circ} \mathrm{C}$, the formulations containing rutin had similar decay for the ability to scavenge free radicals.

The formulations' viscosity varied slightly as time passed, possibly due to the formulation's water loss through evaporation under the storage conditions, mainly under $40.0^{\circ} \mathrm{C} \pm 0.5^{\circ} \mathrm{C}$. Both presented a similar rheological profile behavior during stability.

When analyzing the photoprotective efficacy data it could be noticed that rutin did not have an influence on the formulation's efficacy neither at the initial moment (t0) nor as time progressed (until t60). Therefore, rutin did not influence the functional stability of the cosmetic emulsions under the adopted test conditions. This might have been due to its low concentration on the formulation, which suggests the necessity to evaluate its influence at a higher concentration.

\section{Conclusion}

Formulations presented $\mathrm{pH}$ values compatible with human skin $(4.5-6.5)$ and the rheological profile determination demonstrated that formulations presented similar behavior. They were classified as non-Newtonian and thixotropic.

There were interactions between chemical and physical filters and rutin, which caused changes in the antioxidant activity of the flavonoid. It was concluded that the ideal formulation should have just one of the chemical filters in the maximum concentration and that the inorganic filter should be at the minimal concentration.

The formulation containing rutin at a concentration $0.1 \%(\mathrm{w} / \mathrm{w})$ showed a synergy in increasing the SPF when associated with the chemical and physical filters. However, only the formulation F16 possessed

\section{Discussão}

As formulações contendo rutina apresentaram valores de $\mathrm{pH}$ ligeiramente mais elevados durante todo o teste de estabilidade. Os valores de $\mathrm{pH}$ para ambas formulações foram estáveis durante os 60 dias, sob as condições experimentais adotadas e foram compatíveis com o $\mathrm{pH}$ fisiológico da pele humana.

Em relação à atividade antirradicalar, os valores da percentagem de sequestro de radical livre foram elevados para as formulações contendo rutina, conforme o esperado. Notou-se um decaimento da atividade antirradicalar nas amostras contendo rutina ao longo do tempo, mas as amostras da condição 5,0 \pm $0,5^{\circ} \mathrm{C}$ permaneceram mais estáveis no que diz respeito à atividade antirradicalar. Nas condições de armazenamento de $24,0 \pm 2,0$ e $40,0 \pm 0,5^{\circ} \mathrm{C}$, as formulações contendo rutina apresentaram decaimento semelhante em relação à porcentagem de sequestro de radicais livres.

A viscosidade aparente das formulações variou ligeiramente com o tempo, possivelmente devido à perda de água da formulação por evaporação nas condições de armazenamento, principalmente em $40,0^{\circ} \mathrm{C} \pm 0,5^{\circ} \mathrm{C}$. Ambas apresentaram um perfil reológico semelhante durante a estabilidade.

Ao analisar os dados de eficácia fotoprotetora notou-se que a rutina não influenciou na eficácia da formulação, nem no momento inicial (T0), e nem com o passar do tempo (até T60). Portanto, a rutina não influenciou a estabilidade funcional das emulsões cosméticas sob as condições de teste aprovados. Isto pode ter sido devido à sua baixa concentração na formulação, o que sugere a necessidade de avaliar a sua influência em uma concentração mais elevada.

\section{Conclusão}

As formulações apresentaram valores de $\mathrm{pH}$ compatíveis com a pele humana $(4,5-6,5)$ e a determinação do perfil reológico demonstrou que as formulações apresentaram comportamento semelhante. Elas foram classificadas como nãonewtonianas e tixotrópicas.

Houve interação entre filtros químicos, físicos e a rutina, o que causou mudanças na atividade antioxidante do flavonoide. Concluiu-se que a formulação ideal deverá ter apenas um dos filtros químicos na concentração máxima e que o filtro inorgânico deve estar na concentração mínima.

A formulação contendo rutina na concentração $0,1 \%$ $(\mathrm{p} / \mathrm{p})$ mostrou um aumento sinérgico do FPS quando associada com os filtros químicos e físicos. No entanto, apenas a formulação F16 possuía diferença 
statistical difference in relation to others, offering higher FPS.

The formulations were stable under the adopted conditions concerning the organoleptical characteristics (aspect, color and odor). The most significant modification observed was on the color at the stove storage condition $\left(40.0^{\circ} \mathrm{C} \pm 0.5^{\circ} \mathrm{C}\right)$, which was already expected as it was a more drastic condition. However, this color alteration did not influence the photoprotective efficacy on the physicochemical parameter evaluated. The other modifications that were observed during the storage period were considered as too slight and did not justify the reproval of the formulations. The photoprotective efficacy in vitro was stable in all the storage conditions. The antioxidant activity was stable only when stored at $5.0 \pm 0.5^{\circ} \mathrm{C}$.

In vitro assays have great importance for the functional characterization of the prediction of safety and to elucidate the potential use of active components used in various cosmetic products. This is because they present experimental convenience, they are cost and time efficient, and have adequate reproducibility. The results obtained by these tests justify the selection of active ingredients or formulations evaluated in sequential steps of the study ${ }^{[9 ; 15 ; 16 \text {; }}$ 17]

\section{Acknowledgments}

FAPESP - São Paulo Research Foundation Support

\section{Conflict of interests}

The authors declare that there are no financial and personal relationships that could be viewed as presenting a potential conflict of interests. estatística em relação às demais, oferecendo um valor de FPS mais alto.

As formulações foram estáveis sob as condições adotadas, em relação às características organolépticas (cor, aspecto e odor). A modificação mais significativa observada foi a mudança de cor na condição de armazenamento estufa $\left(40,0^{\circ} \mathrm{C} \pm 0,5^{\circ} \mathrm{C}\right)$, o que já era esperado, pois era a condição mais drástica. No entanto, esta alteração de cor não influenciou a eficácia fotoprotetora nem o parâmetro físicoquímico avaliado. As demais modificações observadas durante o período de armazenamento foram consideradas pequenas e não justificaram a reprovação das formulações. A eficácia fotoprotetora in vitro foi estável em todas as condições de armazenamento. A atividade antirradicalar foi estável apenas para formulações armazenada a $5,0 \pm 0,5^{\circ} \mathrm{C}$.

Ensaios in vitro têm grande importância para a caracterização funcional, para a predição de segurança e para elucidar o uso potencial de componentes ativos utilizados em vários produtos cosméticos, porque apresentam conveniência experimental, custo e tempo para execução reduzidos, e reprodutibilidade adequada. A partir dos resultados obtidos por estes ensaios, há a possibilidade de anteriormente justificar a seleção de ingredientes ativos ou formulações a serem avaliadas em passos sequenciais do estudo ${ }^{[9,15,16 ; 17]}$.

\section{Agradecimentos}

FAPESP - Fundação de Amparo à Pesquisa do Estado de São Paulo

\section{Conflito de interesses}

Os autores declaram que não existem relações financeiras e pessoais que poderam ser vistas como apresentando um potencial conflito de interesses.

\section{References / Referências}

[1]. Svobodova A, Walterova D, Vostalova J. Ultraviolet light induced alteration to the skin. Biomedical papers of the Medical Faculty of the University Palacký, Olomouc, Czechoslovakia 2006; $25: 38-1$.

[2]. Nole G, Johnson AW. An analysis of cumulative lifetime solar ultraviolet radiation exposure and the benefits of daily sun protection. Dermatologic Therapy 2004; 57:62-1.

[3]. Seité S, Fourtanier AMA. The benefit of daily photoprotection. Journal of the American Academy of Dermatology 2008; 160:166-5.

[4]. Madhu A, Pathak MB. Sunscreens: Topical and systemic approaches for protection of human skin against harmful effects of solar radiation. Journal of the American Academy of Dermatology 1982; 258:312-3.

[5]. Kullavanijaya P, Lim H. Photoprotection. Journal of the American Academy of Dermatology 2005; 937:958-6.

[6].Palm MD, O'donoghue MN. Update on photoprotection. Dermatologic Therapy 2007; 360:376-20.

[7]. Schalka S, Addor F. Protetores solares.Grupo editorial Moreira Júnior(serial online) 2006 130
Jan[cited 2010 Jan 18];[5 screens]In: URL: http://www.cibersaude.com.br/revistas.asp? fase $=\mathrm{r} 0$ 03 \&id materia $=3903$

[8]. Velasco MVR, Sarruf FD, Salgado-santos IMN, Haroutiounian-filho CA, Kaneko TM, Baby AR Broad spectrum bioactive sunscreens. Internacional Journal of Pharmaceutics 2008; 50:57-1/2.

[9]. Velasco MVR, Balogh TS, Pedriali CA, SarrufFD, Pinto CASO, Kaneko TM, Baby AR. Associação da Rutina com p-metoxicinamato de octila e benzofenona-3: Avaliação In Vitro da Eficácia Fotoprotetora por Espectrofotometria de Refletância. Latin American Journal of Pharmacy 2008; 23:27-1. [10].Baby AR, Haroutiounian-filho CA, Sarruf FD, Tavante-junior CR, Pinto CASO, Zague V, Arêas EPG, Kaneko TM, Velasco MVR. Estabilidade e estudo de penetração cutânea in vitro da rutina veiculada em uma emulsão cosmética através de um modelo de biomembrana alternativo. Revista Brasileira de Ciências Farmacêuticas 2008; 233:248-2.

[11]. Springsteen A, Yurek R, Frazier M, Carr KF. In vitro measurement of sunprotection factor of sunscreens by diffuse transmittance. Analytica Chimica Acta 1999; 155:164-2:3

[12]. Diffey BL, Tanner PR, Matts PJ, Nash JF. In vitro assessment of the broad-spectrum ultraviolet protection of sunscreen products. Journal of the American Academy of Dermatology 2000; 1024:1035-6.

[13]. Bondet V, Brand-williams W, Berset C. Kinetics and mechanisms of antioxidant activity using the DPPH free radical method. LebensmittelWissenschaft und-Technologie 1997; 609:615-30. [14]. Huang D, Ou B, Prior RL. The chemistry behind antioxidant capacity assays. Journal of Agricultural and Food Chemistry 2005;1841:1856-53.

[15]. Baby AR, Migliato KF, Maciel CPM, Zague V, Pinto CASO, Salgado HRN, Kaneko TM, Velasco MVR. Accelerated chemical stability data of $\mathrm{O} / \mathrm{W} /$ fluid emulsions containing the extract of Trichilia catigua Adr. Juss (and) Ptychopetalum olacoides Bentham. Revista Brasileira de Ciências Farmacêuticas 2007; 405:412-3.

[16]. Maia CPMBM. Desenvolvimento de produtos cosméticos. Cosmetic and Toiletries 2002; 66:69-14.

[17]. Bendová H, Akrman J, Krejcí A.; Kubác L, Jírová D, Kejlová K, Kolárová H, Brabec M, Malý M. In vitro approaches to evaluation of sun protection factor. Toxicology in Vitro, 2007; 1268:1275-7, v.21. 